\title{
Partial Characterization of a Closterovirus Associated with Apple Mealybug-Transmitted Little Cherry Disease in North America
}

\author{
K. C. Eastwell and M. G. Bernardy
}

First author: Washington State University-IAREC, Prosser 99350; and second author: Pacific Agri-Food Research Centre, Agriculture \& Agri-Food Canada, Summerland, British Columbia VOH 1 Z0. Accepted for publication 11 November 2000.

\begin{abstract}
Eastwell, K. C., and Bernardy, M. G. 2001. Partial characterization of a closterovirus associated with apple mealybug-transmitted little cherry disease in North America. Phytopathology 91:268-273.

Little cherry disease (LChD) is a serious economic problem of sweet cherry production in western North America where apple mealybug is the principle vector. $\mathrm{LChD}$ is associated with a distinct species of doublestranded (ds) RNA. In this study, filamentous virus particles were puri-

RNA corresponding to the previously reported dsRNA isolated from infected trees. The virus particles were characterized and were similar to monopartite members of the genus Closterovirus. A portion of the genome was sequenced and found to be most closely related to the RNAdependent RNA polymerase of Grapevine leafroll-associated virus-3, a mealybug-transmitted closterovirus. The characteristics of the mealybugtransmitted Little cherry virus in North America are very different from those of a closterovirus associated with a similar disease in Europe.
\end{abstract} fied from LChD-infected trees and shown to contain single-stranded
Little cherry disease (LChD) was first observed in British Columbia, Canada in 1933, and the first published description of the disease appeared in 1936 (4). The disease has now been reported in most areas of the world where sweet cherries (Prunus avium L.) are grown. LChD infection of sensitive cultivars results in fruit with poor size, color, and taste development. Some cultivars of sweet cherry also develop foliar symptoms. Leaf symptoms can range from a slight upward leaf curl as in cv. Lambert, to leaf reddening in cvs. Sam, Deacon, and Canindex 1. Cultivars that express severe leaf symptoms also exhibit pronounced reduction in growth and vigor (6).

The most important vector of LChD in North American orchards is the apple mealybug (Phenacoccus aceris Signoret) (23). When apple mealybug was first introduced into western North America, high population pressure by this insect led to very rapid dissemination of LChD (6). Budding and grafting with infected propagation material are important mechanisms of LChD transmission.

It is assumed that LChD is caused by a virus because bud and graft transmission of the disease has been demonstrated (10). Electron microscopic examination of diseased tissue frequently revealed the presence of filamentous or closterovirus-like particles in phloem parenchyma and companion cells (24). Exceptions were noted in the correlation between presence of these particles and the disease status of the source tissue $(24,25)$ making interpretation difficult. More recently, the apple mealybug-transmitted disease was consistently associated with a double-stranded RNA (dsRNA) of approximately $12.6 \mathrm{kbp}(7,9)$. These data provided presumptive evidence that $\mathrm{LChD}$ is virus induced.

In this study, we demonstrate that the previously reported dsRNA sequence characteristic of infected tissue is associated with filamentous virions. Moreover, biochemical and molecular data are presented that indicate that the etiological agent of mealybug-transmitted LChD is a member of the genus Closterovirus.

Corresponding author: K. Eastwell; E-mail address: keastw@tricity.wsu.edu

Publication no. P-2001-0122-01R

(c) 2001 The American Phytopathological Society

\section{MATERIALS AND METHODS}

Disease stocks. LChD isolate LC5 was obtained from a source in the Okanagan valley of British Columbia, Canada as previously described (9). Briefly, 500 apple mealybug nymphs were reared on virus-tested plum (Prunus domestica) trees; plum is not a host of the LChD agent (28). After an acquisition access period of 3 weeks on a 'Sam' tree expressing characteristic LChD symptoms, first- and second-instar nymphs were transferred to a 'Lambert' tree for an inoculation access period of approximately 8 weeks (23). The test tree was sprayed with insecticide to prevent further spread of disease. The 'Lambert' tree developed fruit symptoms typical of LChD the following season. At this time, buds were collected to inoculate virus-tested 'Lambert' stock trees. The stock culture trees developed fruit symptoms typical of LChD and were used for virus isolations described here.

LChD isolates LC4 and VAX originated from Prunus serrulata cv. Shirofugen and were maintained by budding onto virus-tested stock trees of Prunus avium cv. Lambert and Prunus serrulata cv. Kwanzan, respectively. LChD isolates SP, K137, K91-94, and K90-105 originated from natural field infections of LChD in the Okanagan and Kootenay valley regions of British Columbia, and were maintained by budding onto virus-tested stock trees of Prunus avium cv. Lambert.

Virus purification. A purification procedure based on that of Ragetli et al. (22) was used to isolate virus particles from leaves of 'Lambert' sweet cherry trees exhibiting typical LChD symptoms. Modifications to the original procedure greatly enhanced recovery of virus-like particles. Leaves were collected and used immediately or stored at $4^{\circ} \mathrm{C}$. One hundred leaves from the 'Lambert' stock tree infected with Little cherry virus (LChV) isolate LC5 were triturated in liquid nitrogen with mortar and pestle. The frozen powder was extracted in a blender with $600 \mathrm{ml}$ of cold extraction buffer $\left(25 \mathrm{mM} \mathrm{Na} \mathrm{HPO}_{4}, 25 \mathrm{mM} \mathrm{KH} \mathrm{KO}_{4}\right.$ at $\mathrm{pH} 6.5$, and $1.0 \%$ Triton $\mathrm{X}-100$ ) freshly amended with $30 \mathrm{~g}$ of skim milk powder and $1.9 \mathrm{ml}$ of 2-mercaptoethanol. The mixture was allowed to stand overnight at $4^{\circ} \mathrm{C}$, then centrifuged at $5,500 \times g$ at $4^{\circ} \mathrm{C}$ for $15 \mathrm{~min}$. Finely powdered $\left(\mathrm{NH}_{4}\right)_{2} \mathrm{SO}_{4}$ was added to the supernatant at a rate of $24 \mathrm{~g} / 100 \mathrm{ml}$ of original volume. The sus- 
pension was stirred for $1 \mathrm{~h}$ at $4^{\circ} \mathrm{C}$ and centrifuged at $24,000 \times g$ at $4^{\circ} \mathrm{C}$ for $20 \mathrm{~min}$. The supernatant was collected and centrifuged again as above. The recovered supernatant from the second centrifugation was centrifuged $3 \mathrm{~h}$ at $4^{\circ} \mathrm{C}, 137,900 \times g(42,000 \mathrm{rpm}$, 45 Ti rotor; Beckman Coulter Inc., Fullerton, CA). The pellet was resuspended overnight at $4^{\circ} \mathrm{C}$ in 2 of $\mathrm{ml}$ resuspension buffer (25 mM Na $2 \mathrm{HPO}_{4}, 25 \mathrm{mM} \mathrm{KH} \mathrm{PO}_{4}, \mathrm{pH} 6.5$, and $0.5 \%$ Triton X100) containing $5 \mu \mathrm{l} / \mathrm{ml}$ of 2-mercaptoethanol, then clarified by centrifugation at $10,000 \times g$ for $15 \mathrm{~min}$ at $4^{\circ} \mathrm{C}$. The supernatant was decanted into a polyallomer centrifuge tube $(1 \times 3.5$ in $)$ and underlaid with $10 \mathrm{ml}$ of sucrose cushion $(20 \% \mathrm{wt} / \mathrm{vol}$ sucrose in resuspension buffer) and centrifuged for $8 \mathrm{~h}$ at $103,800 \times g$ $\left(28,000 \mathrm{rpm}, \mathrm{SW} 28\right.$ rotor; Beckman Coulter Inc.) at $4^{\circ} \mathrm{C}$. The supernatant was aspirated from the centrifuge tubes, and the pellet

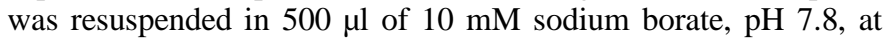
$4^{\circ} \mathrm{C}$ (designated partially purified virus preparation).

Density gradient centrifugation. Further purification of virus particles was achieved by isopycnic density gradient centrifugation in 5-( $N$-2,3-dihydroxy-propyl-acetamido)-2,4,6-triiodo$N, N^{\prime}$ bis(2,3-dihydroxy-propyl)isophthalamide (Nycodenz; Sigma Chemical, St. Louis) (11). In polyallomer tubes, $7.5 \mathrm{ml}$ of Nycodenz stock solution $(65.3 \% \mathrm{wt} / \mathrm{vol}$ Nycodenz in $0.05 \mathrm{M}$ sodium borate, $\mathrm{pH} 6.8$ ) was added to $2.5 \mathrm{ml}$ of partially purified virus preparation. Paraffin oil was layered on top to fill the centrifuge tube. Samples were centrifuged at $14^{\circ} \mathrm{C}$ and $120,900 \times g$ (42,000 rpm, 70.1Ti rotor; Beckman Coulter Inc.) for $65 \mathrm{~h}$. Fractions of $0.4 \mathrm{ml}$ were collected by displacing the gradient from the top with paraffin oil. Densities of the fractions were determined by measuring refractive index at $14^{\circ} \mathrm{C}$ and comparing them with Nycodenz standard solutions of known density (26). Nycodenz was removed by diluting fractions with an equal volume of $0.1 \%$ Triton $\mathrm{X}-100$ in $10 \mathrm{mM}$ sodium borate, $\mathrm{pH}$ 7.8. The solution was passed through a filter membrane (Microcon-100; Millipore Corp., Bedford, MA) by centrifugation for $30 \mathrm{~min}$ at 5,000 rpm. The retentate was diluted with $500 \mu$ of borate buffer and washed again. The washing process was repeated two more times, and the retained material was collected by inverting the columns and centrifugation for $3 \mathrm{~min}$ at 3,500 rpm. The filters were washed twice with $50 \mu \mathrm{l}$ of borate buffer, and the samples were pooled (highly purified virus preparation).

Polyacrylamide gel electrophoresis. Ten microliters of highly purified virus in $40 \mu \mathrm{l}$ of loading buffer was analyzed by discontinuous electrophoresis through a $4 \%$ stacking gel and a $12 \%$ separating gel (17). The resulting gel was silver stained (20). The molecular mass of protein bands was estimated by comparison with low molecular weight markers (Sigma Chemical).

Electron microscopy. Partially purified virus preparations were diluted 1:2 in double distilled water and applied to carbon- and Formvar-coated grids. After allowing the virus to bind for $120 \mathrm{~s}$, grids were washed with 5 drops of water, blotted dry, stained for $45 \mathrm{~s}$ with $1 \%$ uranyl acetate in $50 \mathrm{mM} 2[\mathrm{~N}$-morpholino]ethanesulfonic acid (MES), pH 5.3, and blotted dry. Grids were examined by transmission electron microscopy (100CX; JEOL, Tokyo). Enlarged images of particles and reference grids were measured to determine particle dimensions.

To determine which gradient fraction contained the highest concentration of virions, $18 \mu \mathrm{l}$ of each gradient fraction was mixed with $2 \mu \mathrm{l}$ of 1:20 dilution of polystyrene beads $(53 \mathrm{~nm}$ ) (Bangs Laboratories Inc., Fishers, IN) in $50 \mathrm{mM}$ MES, pH 5.3. The ratio of beads to particles was counted in nine sectors of each grid. Alternatively, hybridization assays described below were used to determine fractions with the highest virus concentrations.

Nucleic acid analysis. The production and evaluation of clone pSLD126 has been described previously (7). The clone was derived from dsRNA isolated from the stock tree infected with apple mealybug-transmitted LChV isolate LC5.

To analyze nucleic acid content of gradient fractions, $80 \mu \mathrm{l}$ of each density gradient fraction was digested with $4 \mu \mathrm{g}$ of protein- ase $\mathrm{K}$ (Sigma Chemical) in $1 \mathrm{mM}$ calcium chloride and $0.5 \%$ sodium dodecyl sulfate (SDS). After $3 \mathrm{~h}$ at $56^{\circ} \mathrm{C}$, the reaction was chilled on ice, $1 \mu \mathrm{l}$ of $250 \mathrm{mM}$ ethylene glycol-bis-( $\beta$-aminoethyl ether) $N, N, N^{\prime}, N^{\prime}$-tetracetic acid at $\mathrm{pH} 8.0$ was added, and the mix was extracted with an equal volume of phenol/chloroform/isoamyl alcohol (24:25:1). The aqueous layer was recovered, and the nucleic acid was precipitated overnight by the addition of $27 \mu \mathrm{l}$ of $10 \mathrm{M}$ ammonium acetate and $370 \mu \mathrm{l}$ of ethanol. The precipitate was collected by centrifugation, briefly air dried, and redissolved in $100 \mu \mathrm{l}$ of water. The sample, mixed with $100 \mu \mathrm{l}$ of $20 \times \mathrm{SSC}=$ $3 \mathrm{M}$ sodium chloride plus $0.3 \mathrm{M}$ sodium citrate, $\mathrm{pH} 7.0$ ) was applied with vacuum to GeneScreen (NEN Life Science Products, Boston) in a slot blot apparatus (Bio-Rad Laboratories, Hercules, $\mathrm{CA})$. The blot was hybridized with a $\left[{ }^{32} \mathrm{P}\right]$-labeled probe as previously described (7).

Cloned DNA represented by pSLD126 was sequenced in both directions by the dideoxy-chain terminator method using Sequenase 2.0 (United States Biochemical, Cleveland) and by cycle sequencing (ABI PRISM Dye Terminator, FS; Perkin-Elmer Applied Biosystems, Foster City, CA).

In some instances, amplification products from reverse transcriptase-polymerase chain reaction (RT-PCR) reactions from reference trees were sequenced directly by cycle sequencing. The sequence of pSLD126, derived in this study, was used to design primers for RT-PCR. Leaf tissue $(0.5 \mathrm{~g})$ was ground in $2 \mathrm{ml}$ of $30 \mu \mathrm{M} 2$-mercaptoethanol, centrifuged, and the supernatant layer diluted 10 -fold with distilled water. To a microfuge tube containing $50 \mu \mathrm{l}$ of $10 \%$ Triton $\mathrm{X}-100,450 \mu \mathrm{l}$ of the diluted extract was added, heated to $65^{\circ} \mathrm{C}$ for $10 \mathrm{~min}$, and quickly cooled in an ice water bath. To $10 \mu \mathrm{l}$ of the disrupted virus particles, $2 \mu \mathrm{l}$ of $60 \mu \mathrm{M}$ methyl mercury hydroxide was added and the mix was incubated for $10 \mathrm{~min}$ at room temperature. One microliter of $260 \mu \mathrm{M} 2$-mercaptoethanol was added, and the mixture was incubated another 10 min. Reaction mix was added to the RNA to give a 20 - $\mu$ l reaction volume containing $1 \times$ RT buffer (Life Technologies, Rockville, MD), $10 \mathrm{mM}$ dithiothreitol, $125 \mu \mathrm{M}$ each $\mathrm{dNTP}, 1.25 \mu \mathrm{M}$ PLC26ex-R primer (5'-AGTAGGCCAGGA-3'), and 100 units of Superscript $\mathrm{II}^{-}$RT (Life Technologies). The reaction was incubated at $40^{\circ} \mathrm{C}$ for $90 \mathrm{~min}$ followed by $90 \mathrm{~s}$ at $96^{\circ} \mathrm{C}$. The entire RT reaction was added to $80 \mu \mathrm{l}$ of PCR mix to yield the following reaction conditions: $1 \times$ Taq DNA polymerase buffer $(10 \times=$ $100 \mathrm{mM}$ Tris- $\mathrm{HCl}$ at $\mathrm{pH} 8.8,500 \mathrm{mM} \mathrm{KCl}, 15 \mathrm{mM} \mathrm{MgCl}_{2}, 0.01 \%$ $\mathrm{wt} / \mathrm{vol}$ gelatin) (Stratagene, La Jolla, CA); $200 \mu \mathrm{M}$ each dNTP; $1 \mu \mathrm{M}$ each primer PLC26ex-R and PLC26ex-L (5'-ACTTCGTCGCTT-3'); and $0.025 \mathrm{unit} / \mu \mathrm{l}$ of Taq DNA polymerase (Stratagene). The mix was subjected to thermocyling with the following profile: 1 cycle at $96^{\circ} \mathrm{C}$ for $90 \mathrm{~s} ; 40$ cycles at $94^{\circ} \mathrm{C}$ for $30 \mathrm{~s} ; 45^{\circ} \mathrm{C}$ for $30 \mathrm{~s}$, and $72^{\circ} \mathrm{C}$ for $30 \mathrm{~s}$, followed by 1 cycle at $72^{\circ} \mathrm{C}$ for $5 \mathrm{~min}$. Five microliters of the reaction was used as the template for a second, nested PCR reaction, in which the reaction conditions were identical to the first except the primers. The primers used were PLC26-R (5'-GCAGTACGTTCGATAAGAG$3^{\prime}$ ) and PLC26-L (5'-AACCACTTGATAGTGTCCT-3'). Products were resolved by agarose gel electrophoresis and isolated from a gel slice with the Qia-Quick Kit (Qiagen, Valencia, CA). The PCR products were sequenced in both directions by cycle sequencing with primers PLC26-L and PLC26-R.

DNA sequence of plasmid pSLD126 was compared with nucleotide sequences in GenBank database using BLASTn version 2.0 algorithm (3). The predicted amino acid sequence of protein encoded by the cloned sequence was compared with database protein sequences by the BLASTx version 2 algorithm (3). The following sequences were obtained from GenBank for further analysis: Beet yellow stunt virus (Accession No. U51931); Beet yellows virus (BYV, Accession No. AF056575, California isolate); Sugar beet yellows virus (SBYV, Accession No. A49282); Citrus tristeza virus (Accession No. U16304, isolate T36); Grapevine leafroll-associated virus-3 (GLRaV-3, Accession No. 
AF037268, isolate NY1); GLRaV-2 (Accession No. AF039204); Lettuce infectious yellows virus (LIYV, Accession No. U15440, isolate 92); and Little cherry virus (LChV-UW2, Accession No. Y10237, isolate UW2). Using the search results as a guide, final alignment of amino acid sequences was obtained with XESEE version 3.0 manual alignment program (5). The resulting aligned fragments were compared with Phylip software (version $3.5 \mathrm{c}$, Felsenstein, Department of Genetics, University of Washington, Seattle). Apple stem grooving virus (ASGV, Accession No. D14995), a Capillovirus, was used as outgroup. The program SEQ-BOOT was used to generate 100 random bootstrap replicates of the data set in order to place confidence limits on the phylogeny predicted by PROTPARS. A majority rule consensus tree was generated by the CONSENSE program.

Orientation of encapsidated RNA was confirmed by RT-PCR. Thirteen microliters of gradient fraction was combined with $0.25 \mu \mathrm{l}$ of either $100 \mu \mathrm{M}$ primer PLC26-R or PLC26-L, heated to $96^{\circ} \mathrm{C}$ for $90 \mathrm{~s}$, and quickly cooled in ice water. A RT reaction mix was added to the above virus/primer solution to yield the

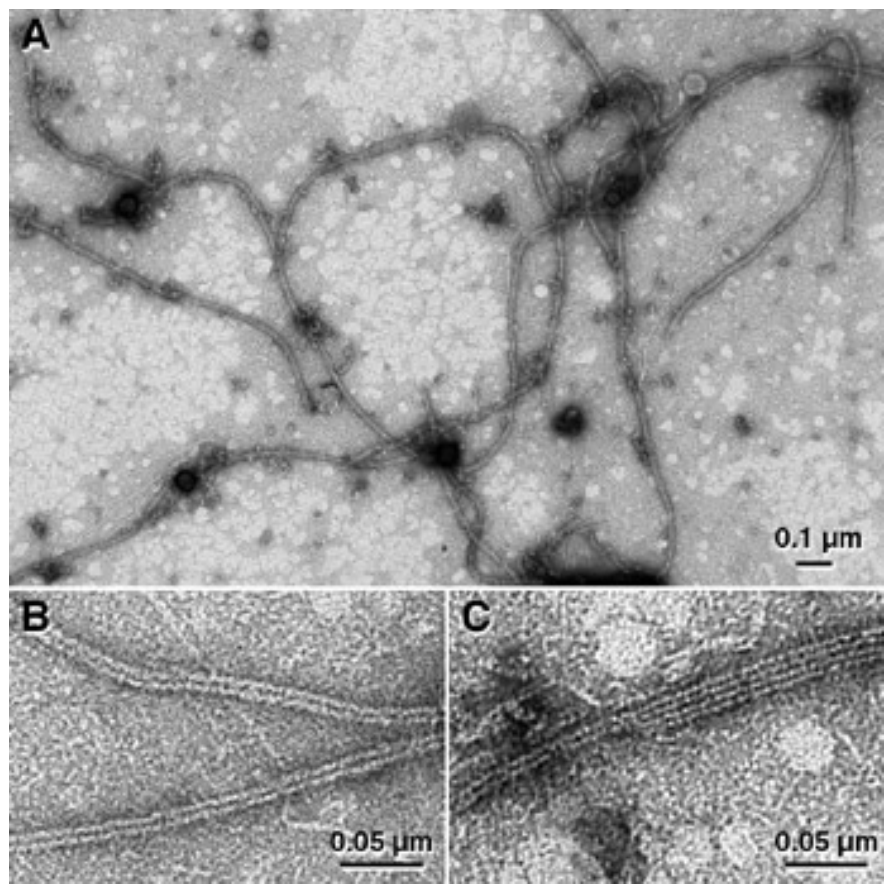

Fig. 1. Electron micrographs of filamentous particles associated with Little cherry virus (LChV) in North America. A, Closterovirus-like particles observed in highly purified preparations of LChV. B and C, Striations evident on these particles are characteristic of many closteroviruses.

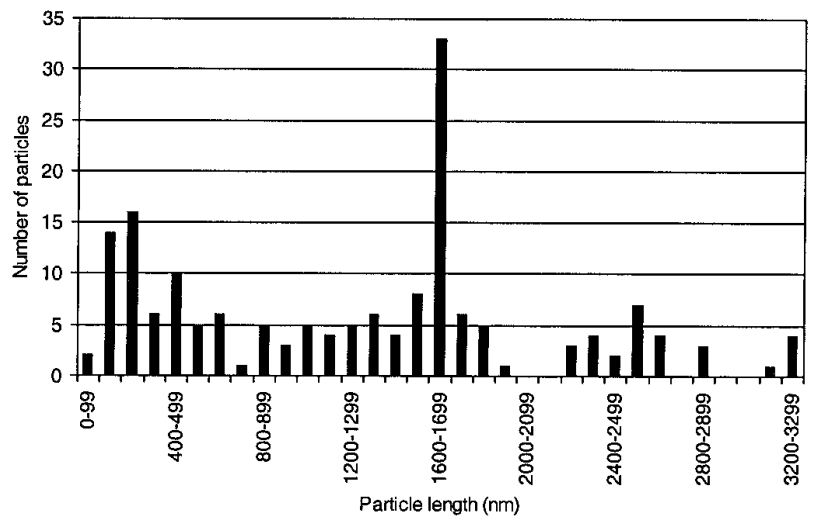

Fig. 2. Histogram showing the distribution of particle lengths in partially purified preparations of Little cherry virus. following concentrations in a $20-\mu \mathrm{l}$ reaction volume: $1 \times \mathrm{RT}$ buffer, $10 \mathrm{mM}$ dithiothreitol, $125 \mu \mathrm{M}$ each dNTP, 200 units of Superscript $\mathrm{II}^{-}$. The reaction mix was incubated at $37^{\circ} \mathrm{C}$ for $90 \mathrm{~min}$, followed by $90 \mathrm{~s}$ at $96^{\circ} \mathrm{C}$, and final cooling on ice. Five microliters of first strand reaction product was added to $45 \mu \mathrm{l}$ of PCR mix to give the following concentrations: $1 \times$ Taq DNA polymerase buffer (Stratagene); $200 \mu \mathrm{M}$ each dNTP; $1 \mu \mathrm{M}$ each primer PLC26-L and PLC26-R; and 0.025 units/ $\mu$ l of Taq DNA polymerase. The mix was subjected to thermocyling with the following profile: 1 cycle at $96^{\circ} \mathrm{C}$ for $90 \mathrm{~s} ; 30$ cycles at $94^{\circ} \mathrm{C}$ for $30 \mathrm{~s} ; 58^{\circ} \mathrm{C}$ for $30 \mathrm{~s}$, and $72^{\circ} \mathrm{C}$ for $30 \mathrm{~s}$, followed by 1 cycle at $72^{\circ} \mathrm{C}$ for $5 \mathrm{~min}$. Products were resolved by agarose gel electrophoresis.

\section{RESULTS}

Particle isolation. Long flexuous virus particles were isolated from trees displaying symptoms of LChD (Fig. 1A). Striations were visible along segments of the particles (Fig. 1B and C). Prunus avium cv. Lambert yielded greater amounts of virus and viral dsRNA (7) than Prunus serrulata, a host previously used as a source of virus particles (22). Therefore, infected 'Lambert' trees were used as virus source in all subsequent experiments. Leaves harvested 4 to 6 weeks after fruit maturation until leaf drop provided the best tissue for virus isolation. As suggested by Ragetli et al. (22), milk provided excellent protection for the virus particles during extraction and isolation. The omission of milk powder or replacement of milk powder with either soluble (polyvinylpyrrolidone, albumin, gelatin) or insoluble (polyvinylpolypyrrolidone, hide powder) amendments failed to result in appreciable recovery of virus particles. The addition of Triton X-100 throughout the purification procedure reduced contamination of virus preparations, specifically eliminating vesicles bounded by double membranes associated with trees infected with LChV (24). The use of Triton X-100 and Nycodenz density gradients also reduced the degree of particle aggregation observed by electron microscopy. If Triton X-100 was omitted or if other density gra-

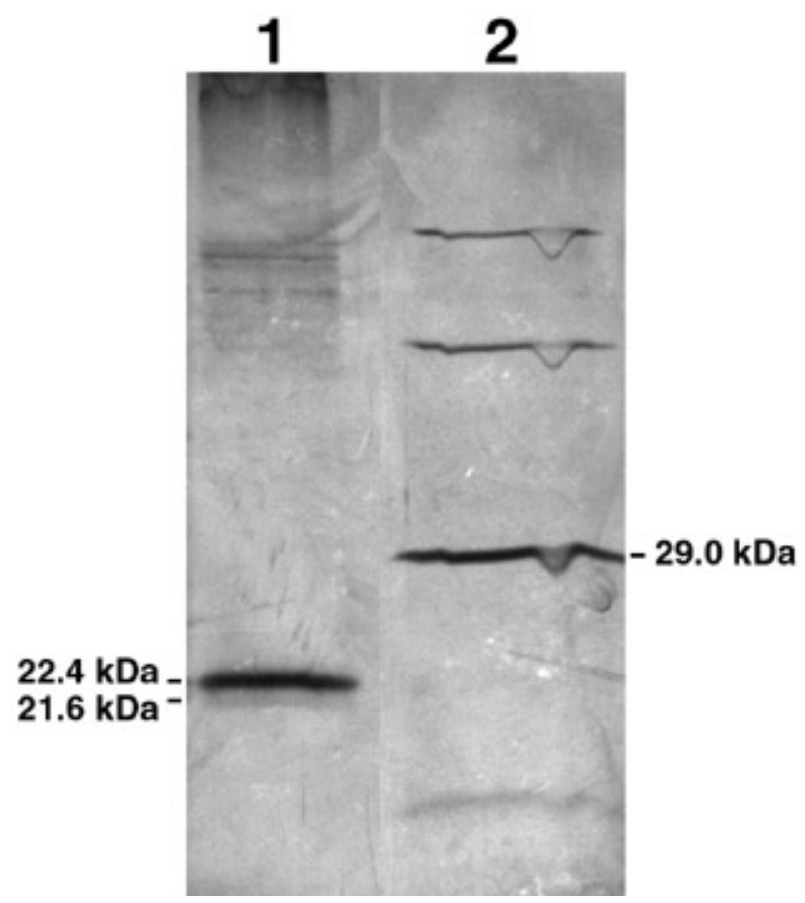

Fig. 3. Sodium dodecyl sulfate-polyacrylamide gel electrophoresis analysis of structural proteins in highly purified preparations of Little cherry virus (LChV). The $12 \%$ separating gel was silver stained. Lane 1, proteins from highly purified preparations of LChV; and lane 2, low molecular weight protein markers for silver staining. 
dient media were used, insoluble virus aggregates formed and large amounts of virus were lost during differential centrifugation. Similarly, the use of polyethylene glycol to concentrate virus particles (22) resulted in significant aggregation of virus particles and reduction in the final yield of highly purified particles. Precipitation by polyethylene glycol was replaced by pelleting the virus through a sucrose cushion. This effectively concentrated the virus particles and removed many contaminating components from the preparation.

The size distribution of particles spanned a wide range, but most particles ranged in length from 1,600 to $1,700 \mathrm{~nm}$ (Fig. 2). Within this range, the average particle length was $1,667 \pm 21 \mathrm{~nm}$ $(n=33)$ and the average width of particles was $11.2 \pm 0.5 \mathrm{~nm}(n=$ 13). Particles frequently bound together to form dimers and higher multimers with an overlap at the junctions rather than end-to-end aggregation. The particle overlap at these unions was $108 \pm 7 \mathrm{~nm}$ $(n=26)$ in length.

SDS-polyacrylamide gel electrophoresis of the highly purified virus revealed a major protein band with an estimated molecular mass of $22.4 \mathrm{kDa}$ (Fig. 3). A minor protein was observed corresponding to a molecular mass of approximately $21.6 \mathrm{kDa}$.

When the virus isolation method described was applied to leaves from sweet cherry trees that do not express LChD symptoms, generally no virus particles were observed at any step during the purification procedure. Gel analysis of samples corresponding to highly purified preparations but extracted from nonsymptomatic trees revealed no proteins corresponding to the $22.4-$ and $21.6-\mathrm{kDa}$ proteins observed in preparations from LChD trees. Similarly, the gradient fractions did not hybridize to probes derived from
pSLD126, nor did they yield specific amplification products with the primers described above. However, some exceptions, less than $10 \%$ of the trees examined, were found. As previously noted (9), some nonsymptomatic trees contain high molecular weight dsRNA that does not hybridize with pSLD126 (Fig. 1, lane 2 in literature citation 9). These nonsymptomatic trees yielded particles that, upon electron microscopic examination, had the same general appearance as particles from $\mathrm{LChD}$ trees. However, particles from nonsymptomatic trees did not hybridize with probes generated from pSLD126 nor did they yield amplification products with LChV-specific primers PLC26-L and -R.

Sequence analysis. The sequence of clone pSLD126 was determined (Fig. 4). For comparison, the nucleic acid sequences of amplification products obtained from several independent sources of LChD are presented. A high degree of identity is observed among all isolates tested (Fig. 4) and indicate that a common agent is present in each of these sources of LChV.

RT-PCR in which the RT reaction from isolated virus particles was primed with one of two primers indicates distinct preferential amplification of the encapsidated RNA with one primer versus the other (Fig. 5). This suggests that only one strand of RNA is encapsidated and that the orientation of the encapsidated RNA is that indicated by the sequence presented in Figure 4.

Sequence comparison of this 543-nucleotide fragment with entries in the GenBank database revealed homology to RNAdependent RNA polymerases (RdRP) of closteroviruses. The segment of the genome represented by clone pSLD126 is that flanking the conserved "GDD" motif of the Sindbis-like family of RdRP (15). The relationship of the deduced amino acid sequence

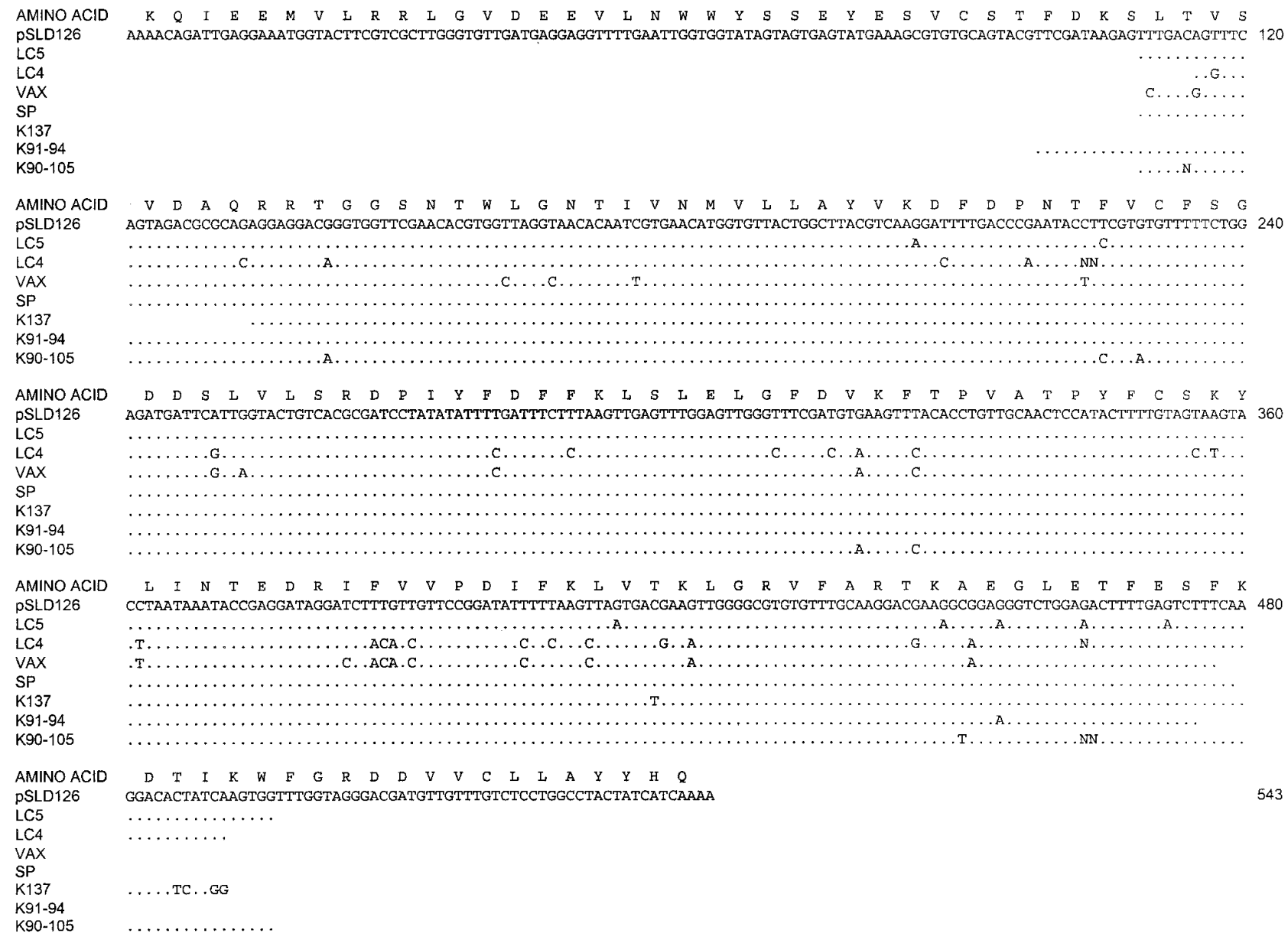

Fig. 4. Partial sequence of Little cherry virus (LChV). The sequence of clone pSLD126 and the deduced amino acid sequence corresponding to this fragment are presented. For comparison, sequences of reverse transcriptase-polymerase chain reaction products from other sources of LChV are given. Dots represent nucleotides identical to those of clone pSLD126. The sequences are shown in the orientation of RNA encapsidated in virions. 
encoded by this sequence (Fig. 4) to the RdRP sequences of other closteroviruses is presented in Figure 6. The "GDD" motif and associated flanking conserved amino acid sequences (15) were used to aid in aligning the protein sequences deduced for other closteroviruses. A phylogenic tree was constructed with the amino acid sequences of this portion of the closterovirus genome. The putative amino acid sequence of LChV isolate LC5 from the current study is most similar to the mealybug-transmitted GLRaV3 (49\% identity and $61 \%$ similarity), whereas the sequence of the European LChV isolate UW2 is more distantly related $(31 \%$ identify and $47 \%$ similarity). When nucleotide sequences are compared, the GLRaV-3 and European LChV isolate UW2 sequences share 51 and $43 \%$ sequence identity, respectively, with the sequence of LChV isolate LC5 determined in this study. Consistent with a previous analysis that compared the entire RdRP coding sequence of several closteroviruses (14), the sequence of LChV isolate UW2 and the whitefly-transmitted LIYV cosegregate on a distinct branch of the phylogenic tree. Both of these sequences have a low degree of amino acid identity and similarity to the predicted amino acid sequence derived from the cloned fragment of LChV isolate LC5.

\section{DISCUSSION}

The virions isolated from leaves infected with the LC5 isolate of LChV are typical of closteroviruses in dimensions. The size reported here is similar to that previously suggested for LChDassociated virus particles (22). The apparent masses of the structural protein subunits of the highly purified LChV virions are consistent with those of most monopartite closteroviruses (1). Although the sequence of the RdRP represented by pSLD126 suggests closest similarity to the sequence of the mealybugtransmitted GLRaV-3, the mass of the LChV structural proteins are relatively small when compared with those of GLRaV-3. The

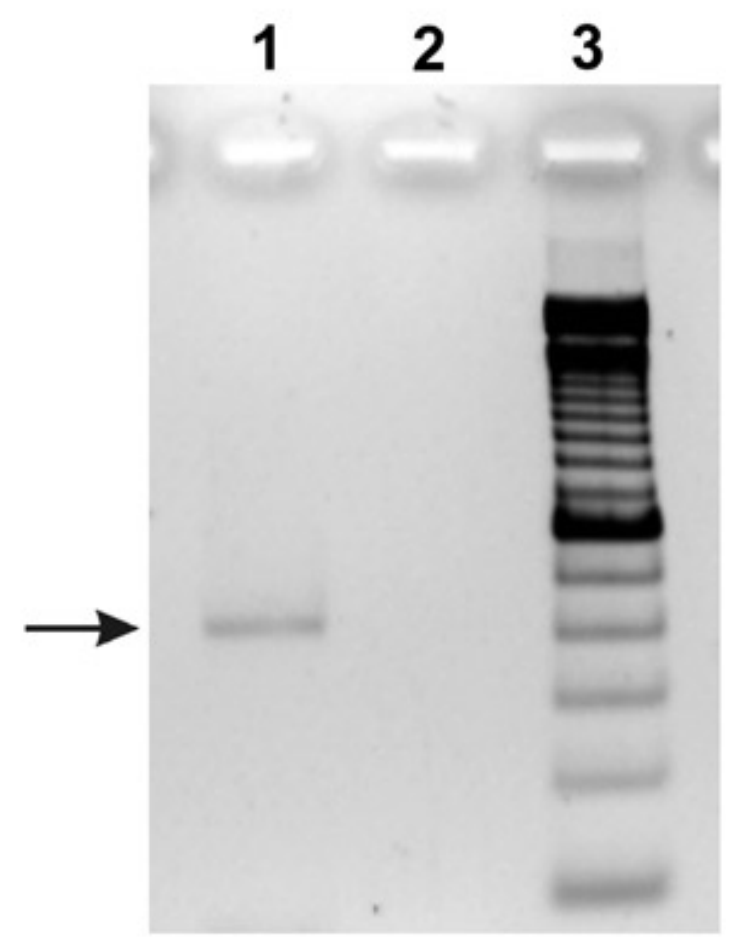

Fig. 5. Agarose gel analysis of reverse transcriptase-polymerase chain reaction (RT-PCR) to determine orientation of the RNA encapsidated in Little cherry virus (LChV) virions. The RT reaction of highly purified $\mathrm{LChV}$ was primed with primer PLC26-R (lane 1) or PLC26-L (lane 2). The products of the RT reaction were subjected to PCR; the arrow indicates the positions of the predicted amplification product based on the sequence of pSLD126. Lane 3, 100-bp DNA ladder. coat protein of GLRaV-3 is estimated to have a mass of $43 \mathrm{kDa}$ by western blot analysis (12), whereas the sequence of GLRaV-3 suggest a molecular mass of $35 \mathrm{kDa}$ for the coat protein (18) and $21 \mathrm{kDa}$ for the duplicate coat protein (19). Based on sequence information, the coat protein and the duplicate coat protein of the UW1 isolate of LChV have molecular masses of 46 and $76 \mathrm{kDa}$, respectively (16). The small apparent mass of the major structural protein relative to that of the European isolate of $\mathrm{LChV}$ and of GLRaV-3 may be the consequence of degradation. Preliminary evidence suggests that specific cleavage of the structural protein may occur during aging of partially purified virions of $\mathrm{LChV}$ isolate LC5 (D. Rochon, personal communication).

BYV is decorated at one end of the particle with antibodies specific for the p24 protein (2). The incorporation of the duplicate coat protein into the $5^{\prime}$ terminal structure of BYV has been confirmed (29). The segment of the virion encapsidated by the duplicate coat protein has an estimated length of $75 \mathrm{~nm}$. This is similar in the length to the adherent regions of overlap (108 nm) observed in highly purified preparations of LChV. The adhesion of virus particles with specific overlap may be a function of altered protein composition in these terminal regions. Further analysis is necessary to determine if the duplicate coat protein is involved in this interaction, and if this interaction occurs in vivo as well as in vitro.

Cherry virus A (CVA), a member of the genus Capillovirus, has been detected in the source trees for European and North American studies of $\mathrm{LChD}$, but there is no correlation between the incidence of CVA and LChD $(8,13)$. CVA was detected in the stock tree of LChV isolate LC5 by RT-PCR (8). The length of ASGV, a member of the genus Capillovirus, is $640 \mathrm{~nm}$ (21), and particles of a similar length would be anticipated for CVA. However, there was no distinct population of particles corresponding to this length in preparations of LChV. Single-stranded RNA isolated from highly purified particles also failed to reveal RNA species of the size anticipated for CVA (data not shown). Therefore, although this virus could be detected by molecular means (RT-PCR), it is present at very low concentration in infected trees and in the highly purified virus preparations of LChV.

There are significant differences between the characteristics of the closterovirus found in LChD-infected trees of North America relative to those reported from Europe. The RNA of European isolate UW2 is considerably larger than the corresponding dsRNA associated with isolate LC5, or other mealybug-transmitted stock

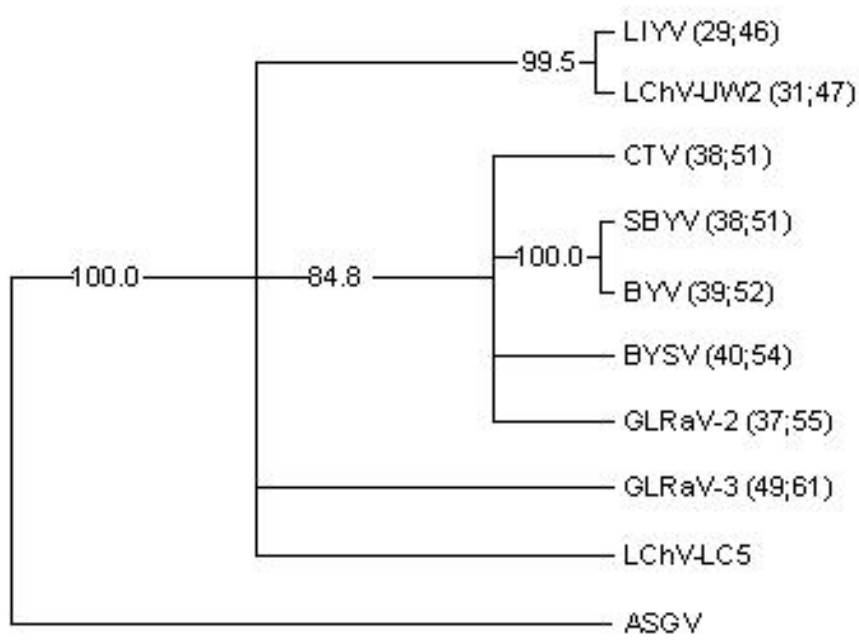

Fig. 6. Dendogram showing the predicted phylogenic relationship of closteroviruses based on the predicted amino acid sequences corresponding to the sequence of pSLD126. Apple stem grooving virus (ASGV) is used as the outgroup. The numbers in parenthesis are (percentage of amino acid identity/ percentage of amino acid identity plus similarity) relative to the predicted amino acid sequence from pSLD126. Only branches represented in more than $60 \%$ of the trees are shown. 
isolates of LChD (7). Some field isolates of LChD from North America did contain higher molecular weight dsRNA (Fig. 1A in literature citation 9), but the larger dsRNA was found in relatively few LChD samples, and was also detected in leaves from symptomless trees (9). In contrast, the 12.6-kbp dsRNA that clone pSLD126 was derived from was present in all LChD-diseased trees tested in British Columbia (9). As discussed above, the observed sizes of structural proteins obtained from LChV isolate LC5 are very different from those predicted from the coding sequence of isolate UW1. The molecular data do not preclude modification of the protein during incorporation into virions or during subsequent isolation. There is also considerable sequence divergence in comparing these two isolates of LChV. The sequence of the European isolate is very similar to the whiteflytransmitted closterovirus sequences (14), whereas the putative RdRP sequence from isolate LC5 is similar to another mealybugtransmitted closterovirus, GLRaV-3. Data suggest that the mealybug-transmitted closterovirus found in diseased trees of North America is distinct from the closterovirus associated with LChDlike symptoms observed in Europe. Mealybug transmission has been a defining component of the description of $\mathrm{LChV}$ since the transmission studies of Raine et al. (23). Although mealybug transmission of LChV isolate LC5 has been demonstrated, this characteristic has yet to be demonstrated for the European isolate UW2 of LChV. Moreover, LChV strain LC5 was obtained from the geographical area where the LChD was first described. Based on these data, strain LC5 should be considered the type strain of LChV.

\section{NOTE ADDED IN PROOF}

As this paper was going to press, we became aware of a study by Rott and Jelkmann (27) describing the partial characterization of a virus that is closely related or identical to the virus described in this paper. This virus has been called Little cherry virus- 2 by those authors.

\section{ACKNOWLEDGMENTS}

We thank R. D. McMullen and C. Jong, formerly of the Pacific AgriFood Research Centre (PARC), for mealybug transmission of LChV; L. Veto and $\mathrm{M}$. Weis at PARC for preparation of electron micrographs; and R. C. Larsen and J. M. Crosslin, USDA-ARS, for presubmission reviews of this manuscript.

\section{LITERATURE CITED}

1. Agranovsky, A. A. 1996. Principles of molecular organization, expression, and evolution of closteroviruses: Over the barriers. Adv. Virus Res. 47:119-158.

2. Agranovsky, A. A., Lesemann, D. E., Maiss, E., Hull, R., and Atabekov, J. G. 1995. "Rattlesnake" structure of a filamentous plant RNA virus built of two capsid proteins. Proc. Natl. Acad. Sci. USA 92:2470-2473.

3. Altschul, S. F., Madden, T. L., Schaffer, A. A., Zhang, J., Zhang, Z., Miller, W., and Lipman, D. J. 1997. Gapped BLAST and PSI-BLAST: A new generation of protein database search programs. Nucleic Acids Res. 25:3389-3402.

4. Anonymous. 1936. British Columbia Department of Agriculture Annual Report.

5. Cabot, E. L., and Beckenbach, A. T. 1989. Simultaneous editing of multiple nucleic acid and protein sequences with ESEE. Cabios 5:233-234.

6. Eastwell, K. C. 1997. Little cherry disease-in perspective. Pages 143-
151 in: Filamentous Viruses of Woody Plants. P. L. Monette, ed. Research Signpost, Triandrum, India.

7. Eastwell, K. C., and Bernardy, M. G. 1996. Association of high molecular weight double-stranded RNA with little cherry disease. Can. J. Plant Pathol. 18:203-208.

8. Eastwell, K. C., and Bernardy, M. G. 1998. Relationship of cherry virus A to little cherry disease in British Columbia. Acta Hortic. 472:305-313.

9. Eastwell, K. C., Bernardy, M. G., and Li, T. S. C. 1996. Comparison between woody indexing and a rapid hybridization assay for diagnosis of little cherry disease in cherry trees. Ann. Appl. Biol. 128:269-277.

10. Foster, W. R., and Lott, T. B. 1947. 'Little cherry', a virus disease. Sci. Agric. 27:1-6.

11. Gugerli, P. 1984. Isopycnic centrifugation of plant viruses in Nycodenz density gradients. J. Virol. Methods 9:249-258.

12. Hu, J. S., Gonsalves, D., Boscia, D., and Namba, S. 1990. Use of monoclonal antibodies to characterize grapevine leafroll disease. Phytopathology 80:920-925.

13. Jelkmann, W. 1995. Cherry virus A: cDNA cloning of dsRNA, nucleotide sequence analysis, and serology reveal a new plant capillovirus in sweet cherry. J. Gen. Virol. 76:2015-2024.

14. Jelkmann, W., Fechtner, B., and Agranovsky, A. A. 1997. Complete genome structure and phylogenetic analysis of little cherry virus, a mealybug-transmissible closterovirus. J. Gen. Virol. 78:2067-2071.

15. Kamer, G., and Argos, P. 1984. Primary structural comparison of RNAdependent polymerases from plant, animal and bacterial viruses. Nucleic Acids Res. 12:7269-7282.

16. Keim-Konrad, R., and Jelkmann, W. 1996. Genome analysis of the 3'terminal part of the little cherry disease associated dsRNA reveals a monopartite clostero-like virus. Arch. Virol. 141:1437-1451.

17. Laemmli, U. K. 1970. Cleavage of structural proteins during the assembly of the head of bacteriophage T4. Nature 227:680-685.

18. Ling, K. S., Zhu, H. Y., Alvizo, H., Hu, J. S., Drong, R. F., Slightom, J. L., and Gonsalves, D. 1997. The coat protein gene of grapevine leafroll associated closterovirus-3: Cloning, nucleotide sequencing and expression in transgenic plants. Arch. Virol. 142:1101-1116.

19. Ling, K. S., Zhu, H. Y., Drong, R. F., Slightom, J. L., McFerson, J. R. and Gonsalves, D. 1998. Nucleotide sequence of the $3^{\prime}$-terminal twothirds of the grapevine leafroll-associated virus-3 genome reveals a typical monopartite closterovirus. J. Gen. Virol. 79:1299-1307.

20. Merril, C. R., Goldman, D., Sedman, S. A., and Ebert, M. H. 1981. U1trasensitive stain for proteins in polyacrylamide gels shows regional variation in cerebrospinal fluid proteins. Science 211:1437-1438.

21. Namba, S. 1995. Genus Capillovirus. Pages 465-467 in: Virus Taxonomy: Sixth Report of the International Committee on Taxonomy of Viruses. F. A. Murphy, C. M. Fauquet, D. H. L. Bishop, S. A. Ghabrial, A. W. Jarvis, G. P. Martelli, M. A. Mayo, and M. D. Summers, eds. Springer-Verlag, Wien, Austria.

22. Ragetli, H. W. J., Elder, M., and Shroeder, B. K. 1982. Isolation and properties of filamentous viruslike particles associated with little cherry disease in Prunus avium. Can. J. Bot. 60:1235-1248.

23. Raine, J., McMullen, R. D., and Forbes, A. R. 1986. Transmission of the agent causing little cherry disease by the apple mealybug Phenacoccus aceris and the dodder Cuscuta lupuliformis. Can. J. Plant Pathol. 8:6-11.

24. Raine, J., Weintraub, M., and Schroeder, B. 1975. Flexous rods and vesicles in leaf and petiole phloem of little-cherry diseased Prunus spp. Phytopathology 65:1181-1186.

25. Raine, J., Weintraub, M., and Schroeder, B. K. 1979. Hexagonal tubules in phloem cells of little cherry-infected trees. J. Ultrastruct. Res. 67: 109-116.

26. Rickwood, D., Ford, T., and Graham, J. 1982. Nycodenz: A new nonionic iodinated gradient medium. Anal. Biochem. 123:23-31.

27. Rott, M. E., and Jelkmann, W. 2001. Detection and partial characterization of a second closterovirus associated with little cherry disease, Little cherry virus-2. Phytopathology 91:261-267.

28. Wilks, J. M., and Welsh, M. F. 1961. Host range studies of the little cherry disease virus. Can. J. Plant Sci. 21:544-548.

29. Zinovkin, R. A., Jelkmann, W., and Agranovsky, A. A. 1998. The minor coat protein of beet yellows closterovirus encapsidates the $5^{\prime}$ terminus of RNA in virions. J. Gen. Virol. 80:269-272. 